\title{
Occurrence and geochemistry of lead-210 and polonium-210 radionuclides in public-drinking-water supplies from principal aquifers of the United States
}

Zoltan Szabo*1, Paul E. Stackelberg ${ }^{2}$, and Charles A. Cravotta III

${ }^{1}$ U.S. Geological Survey, 3450 Princeton Pike, Lawrenceville, New Jersey 08648, United States

${ }^{2}$ U.S. Geological Survey, 425 Jordan Road, Troy, New York 12180, United States

${ }^{3}$ U.S. Geological Survey,215 Limekiln Road, New Cumberland, Pennsylvania 17070, United States

*Corresponding Author, Zoltan Szabo, U.S. Geological Survey, 3450 Princeton Pike, Lawrenceville, New Jersey 08648, United States; e-mail: zszabo@usgs.gov, phone 609-771-3929 


\section{List of Supplemental Figures (This PDF)}

Figure SI-1. ${ }^{238} \mathrm{U}$ decay series with half-lives.

Figure SI-2. Time-series plot of concentrations is shown for (A) ${ }^{210} \mathrm{~Pb}$ and (B) ${ }^{210} \mathrm{Po}$ from 2012 to 2018 for field blanks, Internal Laboratory Method Blanks, certified trace-element free blank source waters, and the USGS groundwater samples.

Figure SI-3. Frequency distribution of concentrations of (A) ${ }^{210} \mathrm{~Pb}$ and of (B) ${ }^{210} \mathrm{Po}$ for all samples and samples grouped by the primary bedrock lithologies.

Figure SI-4. Boxplots showing the distribution of ${ }^{222} \mathrm{Rn}, \mathrm{pH}, \mathrm{Na} / \mathrm{Cl}$ molar ratios, dissolved oxygen, and percent modern carbon-14 $\left({ }^{14} \mathrm{C}\right)$ grouped by whether detected concentrations for $(\mathrm{A}){ }^{210} \mathrm{~Pb}$ were less than or greater than $1.0 \mathrm{pCi} / \mathrm{L}$, and $(\mathrm{B}){ }^{210} \mathrm{Po}$ were less than or greater than $0.7 \mathrm{pCi} / \mathrm{L}$.

Figure SI-5. Boxplots showing the distribution of effective distribution coefficients for (A) ${ }^{210} \mathrm{~Pb}$ and (B) ${ }^{210}$ Po by redox category.

Figure SI-6. Aqueous speciation of dissolved lead $(\mathrm{Pb})$ as a function of $\mathrm{pH}$ for groundwater samples from the Atlantic and Gulf Coastal Plain principal aquifers: (A) percentage of dissolved $\mathrm{Pb}$ as carbonate complexes $\left(\mathrm{PbCO}_{3}\right.$ and $\left.\mathrm{Pb}\left(\mathrm{CO}_{3}\right)_{2}{ }^{-2}\right)$ in the presence of concentrations of sulfide at equilibrium with pyrite, and (B) Eh-pH diagram showing predominant aqueous $\mathrm{Pb}$ species.

Figure SI-7. Eh-pH diagrams for (A) Polonium (Po) without metastable phases and (B) Tellurium (Te). Figure SI-8. Scatter plot of concentration of ${ }^{222} \mathrm{Rn}$ as a function of $\mathrm{pH}$ for Atlantic and Gulf Coastal Plain principal aquifer samples grouped by redox category and ${ }^{210} \mathrm{Po}$ concentration. 


\section{List of Supplemental Tables [Associated Excel File]}

Table S1-1. Abbreviation, principal aquifer, primary bedrock lithology, the number of samples, and detection statistics for ${ }^{210} \mathrm{~Pb},{ }^{210} \mathrm{Po}$ and ${ }^{222} \mathrm{Rn}$.

Table SI-2. Chemical and radionuclide data and redox classification for samples of water collected from public-supply wells for each network.

Table SI-3. Concentrations of ${ }^{210} \mathrm{~Pb}$ and ${ }^{210} \mathrm{Po}$ for field-blank and laboratory-collected deionized-sourcewater (source) blank samples.

Table SI-4. Concentrations of ${ }^{210} \mathrm{~Pb}$ and ${ }^{210} \mathrm{Po}$ for sequential replicate samples.

Table SI-5. Correlation coefficient (Spearman rank-order) for (A) ${ }^{210} \mathrm{~Pb}$ and $(\mathrm{B}){ }^{210} \mathrm{Po}$ by primary bedrock lithology and principal aquifer.

Sheet SI-1. Program to compute aqueous speciation and redox potential on the basis of redox pairs. 


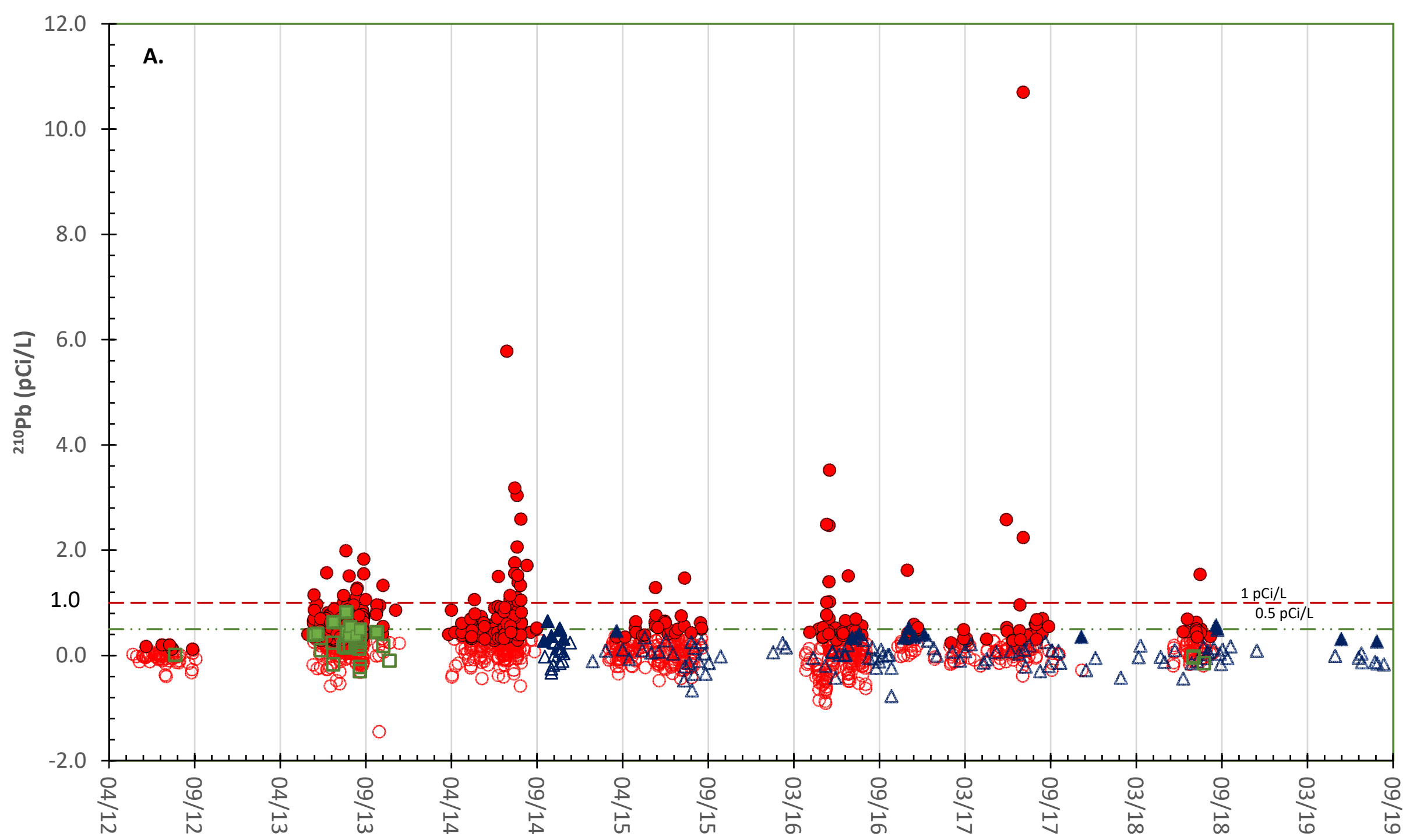

Figure SI-2A. Analytical results grouped as detected values and values less than sample-specific critical levels ( $\mathrm{CLss}^{\mathrm{Ls}}$ ) for ${ }_{210} \mathrm{~Pb}$ in groundwater samples, field blanks, and laboratory-method blanks (MB) over 2012-2018 study period. No field blank or MB had concentration >1.0 pCi/L (human-health based threshold), and <10\% of each had concentration $>0.5 \mathrm{pCi} / \mathrm{L}$ (half human-health based threshold). [Circles: groundwater; squares: field blanks; triangles: MB. Symbols are filled for detected concentrations and open for results $<\mathrm{C}_{\mathrm{Lss}}$. Contract laboratories for ${ }^{210} \mathrm{~Pb}$ and ${ }^{210} \mathrm{Po}$ analyses : Test Americal, Richland, Washington, and ALS Laboratory, Fort Collins, Colorado.] 


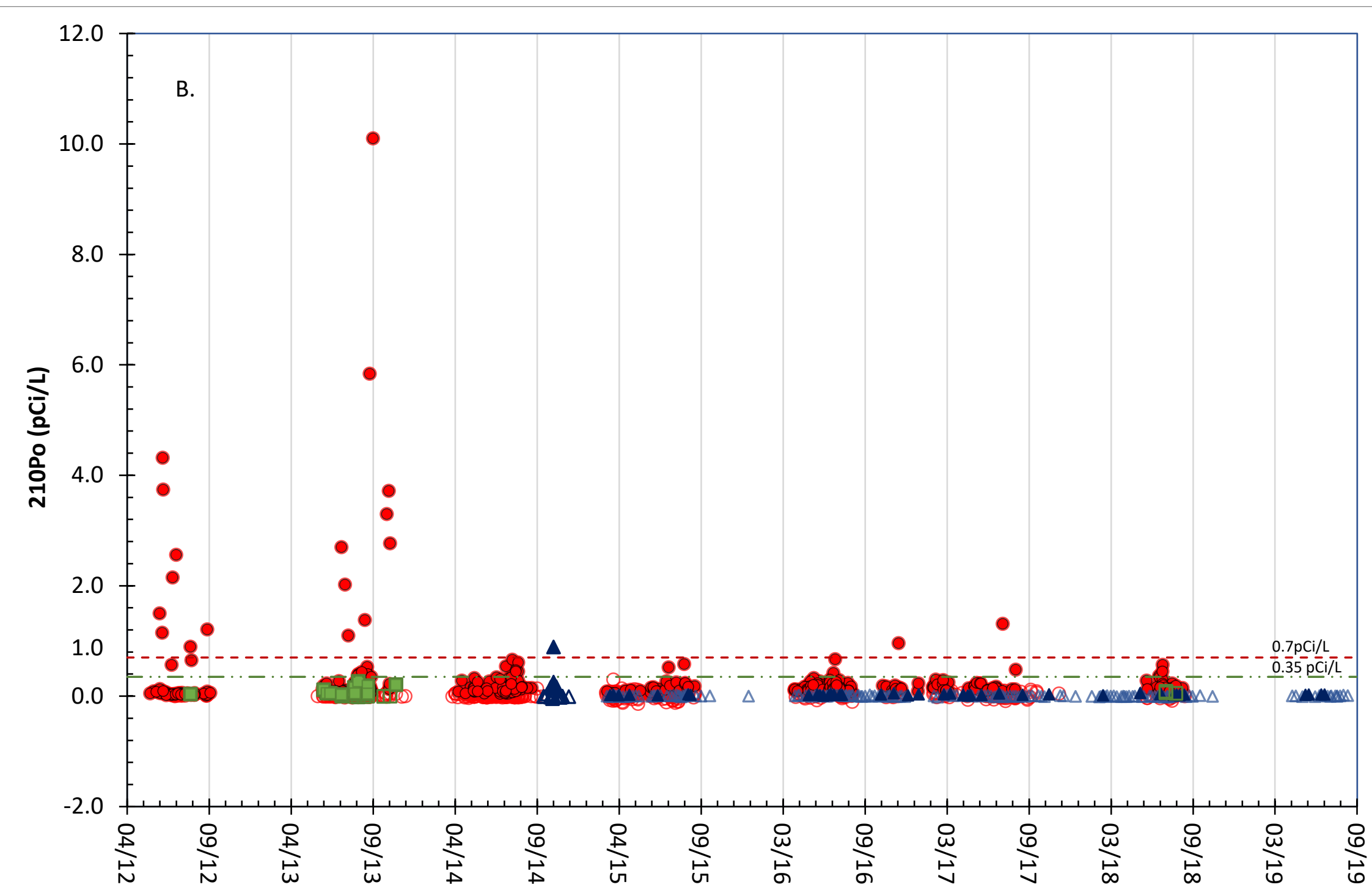

Figure SI-2B. Analytical results grouped as detected values and values less than sample-specific critical levels $\left(\mathrm{C}_{\mathrm{Lss}}\right)$ for ${ }^{210} \mathrm{Po}$ in groundwater samples, field blanks, and laboratory-method blanks (MB) over 2012-2018 study period. No field blank had concentration $>0.35 \mathrm{pCi} / \mathrm{L}$ (half human-health based threshold), and one $\mathrm{MB}$ had concentration $>0.35 \mathrm{pCi} / \mathrm{L}$ and $<0.7 \mathrm{pCi} / \mathrm{L}$ (human-health based threshold). One $\mathrm{MB}$ had concentration $>0.7 \mathrm{pCi} / \mathrm{L}$ but at a time period when groundwater samples from this study were not being analyzed. [Circles: groundwater; squares: field blanks; triangles: MB. Symbols are filled for detected concentrations and open for results $<\mathrm{C}_{\mathrm{Lss}}$.] 

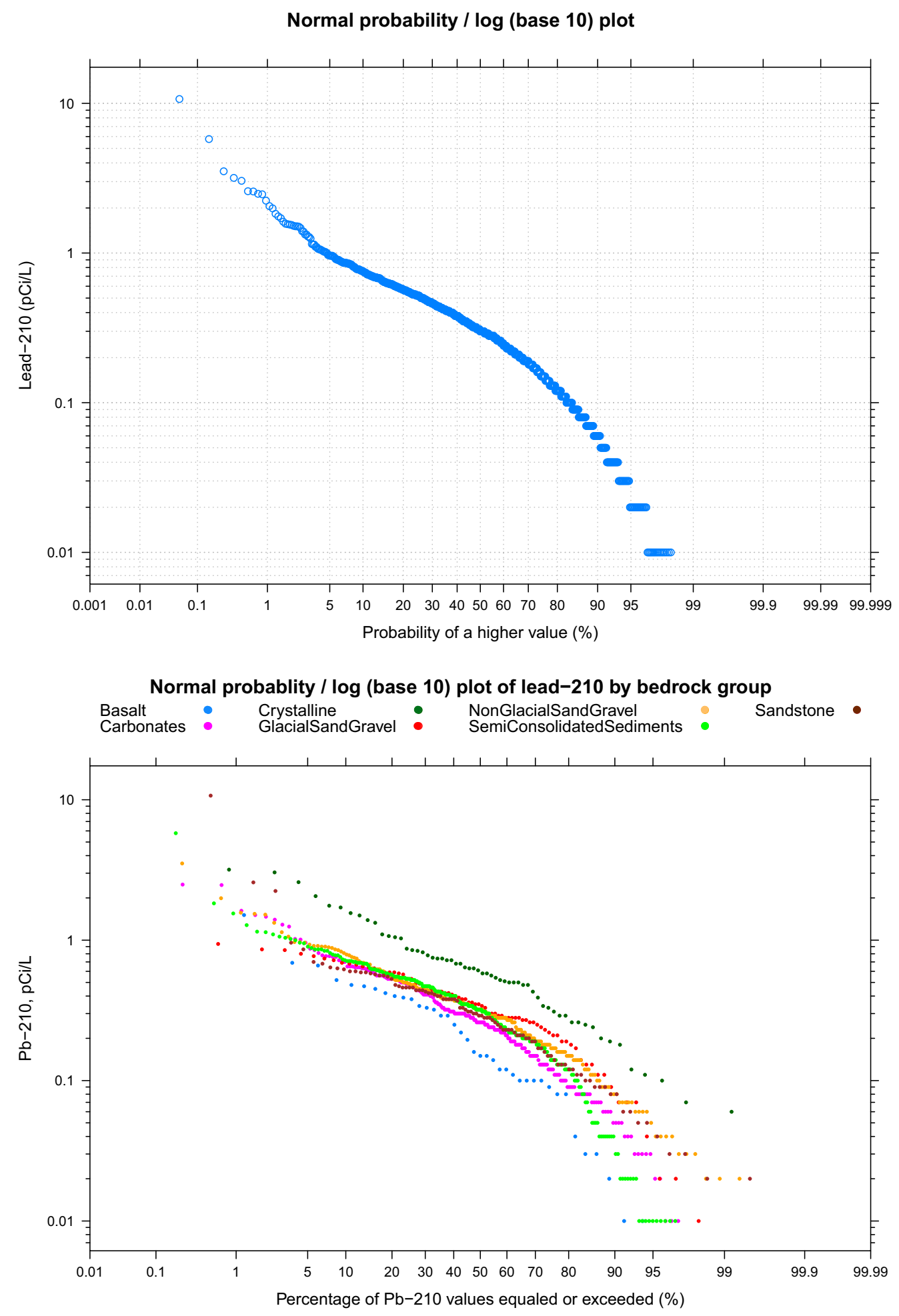

Figure SI.3A Frequency distribution of concentrations of ${ }^{210} \mathrm{~Pb}$ for all samples with reported values $>0$, and samples with reported values $>0$ grouped by the 7 primary bedrock lithologies, showing that samples from the felsic crystalline rocks (Piedmont, dark green) represent a population with higher concentrations than the other primary lithologies, but several other lithologies do have numbers of samples with high concentrations. 

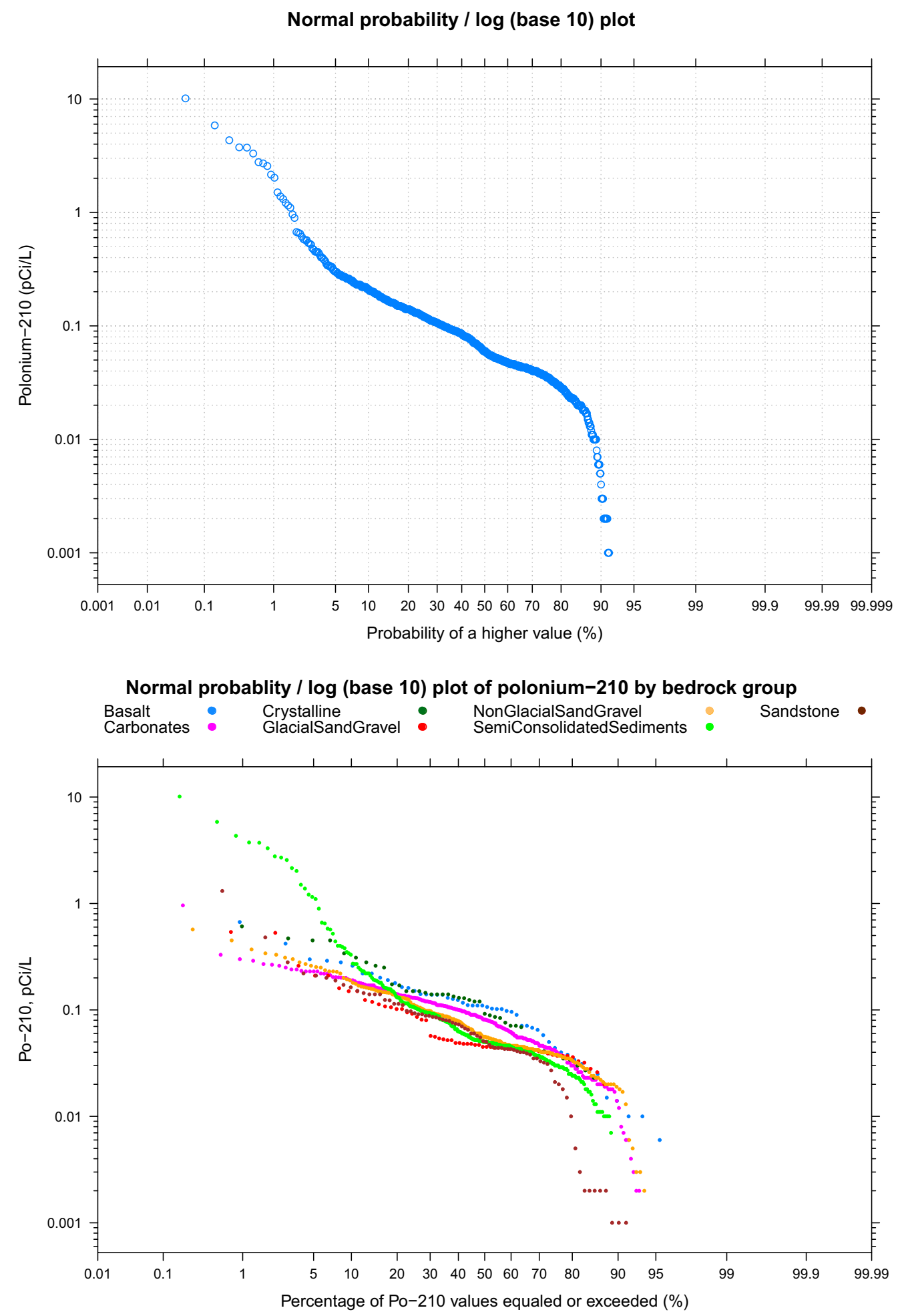

Figure SI.3B Frequency distribution of concentrations of ${ }^{210} \mathrm{Po}$ for all samples with reported values $>0$, and samples with reported values $>0$ grouped by the 7 primary bedrock lithologies, showing that samples from the semi-consolidated sediments from the Atlantic and Gulf Coastal Plain principal aquifers (lime green) represent a population with higher concentrations than the other primary lithologies. 

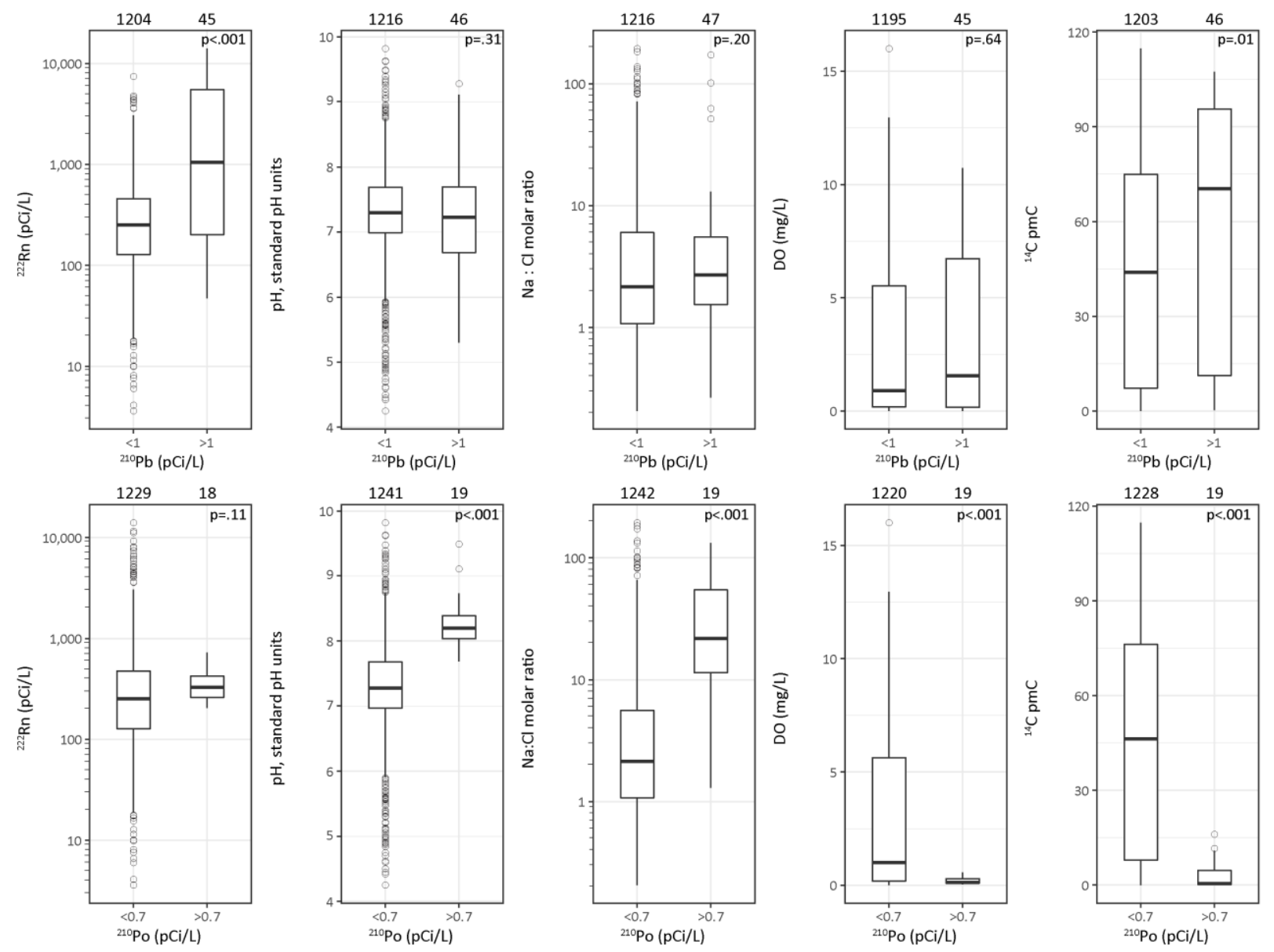

Figure SI-4. Boxplots showing the distribution of ${ }^{222} \mathrm{Rn}, \mathrm{pH}, \mathrm{Na} / \mathrm{Cl}$ molar ratios, dissolved oxygen (DO) and carbon-14 $\left({ }^{14} \mathrm{C}\right)$ grouped by whether $(\mathrm{a}){ }^{210} \mathrm{~Pb}$ or $(\mathrm{b}){ }^{210} \mathrm{Po}$ were less than or greater than or equal to 1.0 or $0.7 \mathrm{pCi} / \mathrm{L}$, respectively. Values above the boxplots indicate the number of samples. p-values indicate the significance of the Wilcoxon Rank Sum test. Boxes represent 25th, 50th, and 75th percentiles; upper whiskers represent the 90th percentile. Outliers shown as open circles. 

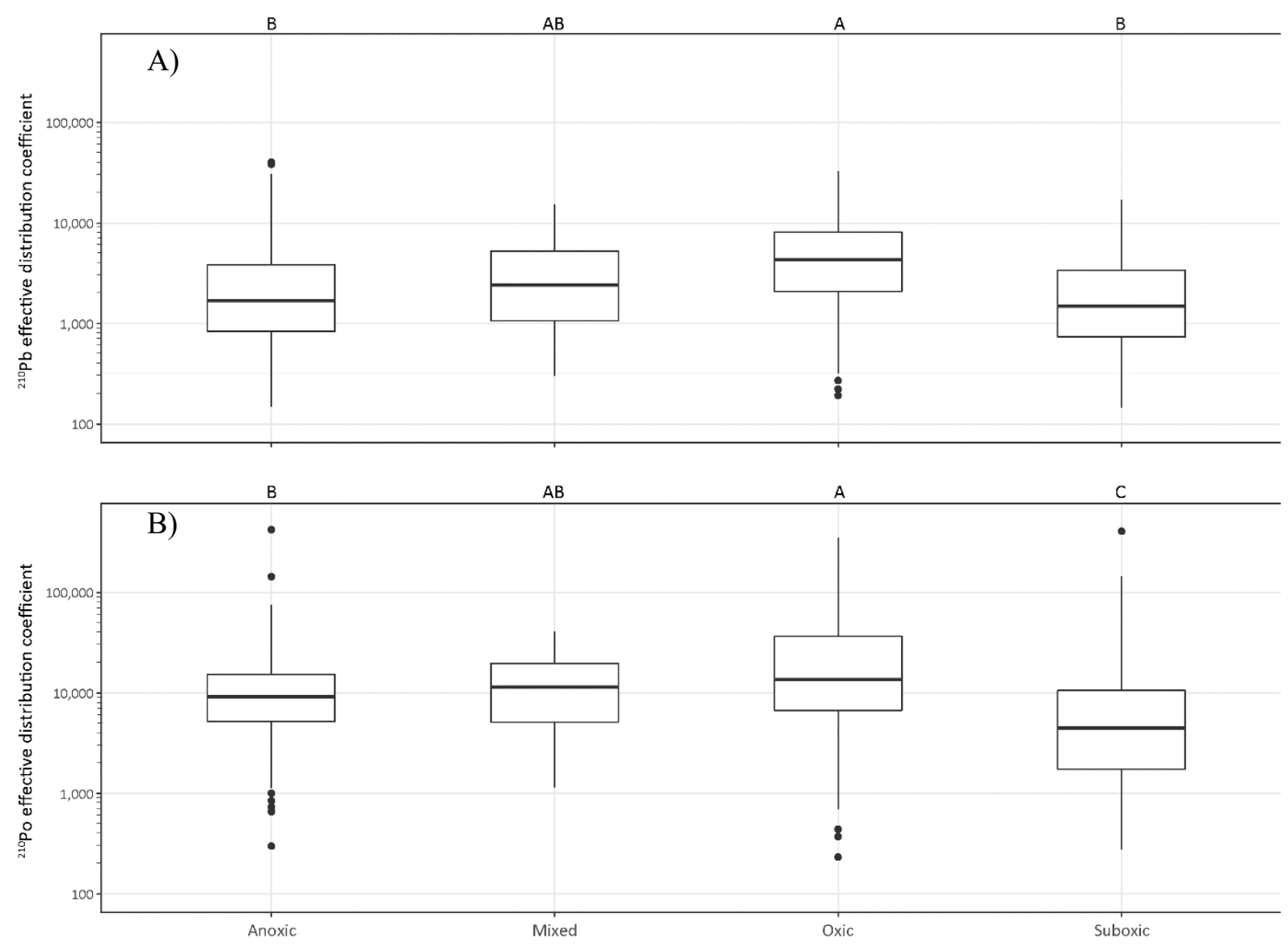

Figure SI-5. Boxplots showing the distribution of effective distribution coefficients for $(\mathrm{A}){ }^{210} \mathrm{~Pb}$ and (B) ${ }^{210}$ Po grouped by redox category. Letters represent the results of Tukey's multiple comparison test. Groups of data with similar letters do not differ significantly. Redox category assignment modified from McMahon and Chapelle $(2008)^{46}$ as described in the manuscript text. Boxes represent 25th, 50th, and 75th percentiles; upper whiskers represent the 90 th percentile. Outliers shown as open circles. 


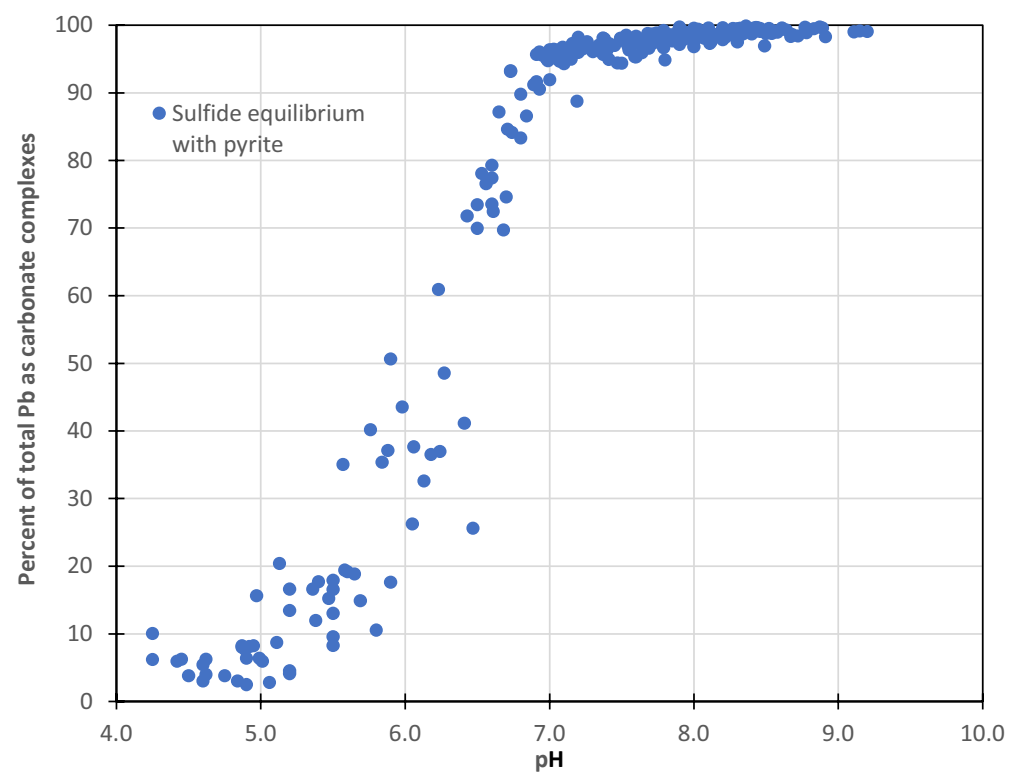

Figure SI.6A.Aqueous speciation of dissolved lead $(\mathrm{Pb})$ as a function of $\mathrm{pH}$ for groundwater samples from the Atlantic and Gulf Coastal Plain principal aquifers: (A) percentage of dissolved $\mathrm{Pb}$ as carbonate complexes $\left(\mathrm{PbCO}_{3}\right.$ and $\left.\mathrm{Pb}\left(\mathrm{CO}_{3}\right)_{2}{ }^{-2}\right)$ in the presence of concentrations of sulfide at equilibrium with pyrite $\left(\Sigma \mathrm{S}=10^{-26.5}\right.$ to $10^{-19.0} \mathrm{M}$ ). The $\mathrm{Pb}$-carbonate complexes predominate except when $\mathrm{pH}$ is $<6.5$ when the $\mathrm{Pb}$ cation is not complexed. 


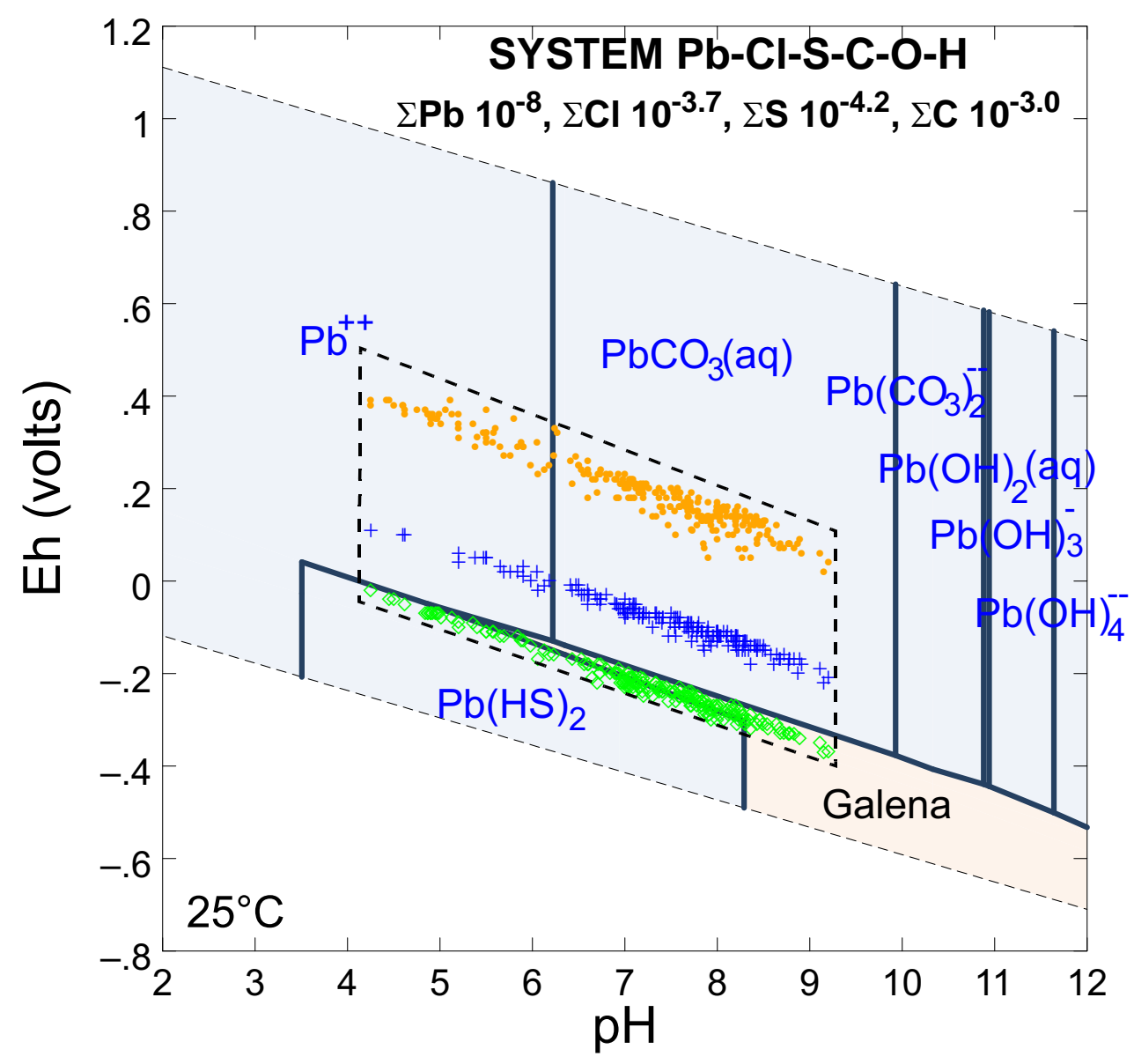

Figure SI.6B. Aqueous speciation of dissolved lead $(\mathrm{Pb})$ as a function of $\mathrm{pH}$ for groundwater samples from the Atlantic and Gulf Coastal Plain principal aquifers (PAs): (B) Eh-pH diagram showing predominant aqueous $\mathrm{Pb}$ species. Assumed chemical activities are $\Sigma \mathrm{Pb}=10^{-8}, \Sigma \mathrm{S}=10^{-4.2}, \Sigma \mathrm{Cl}=10^{-3.7}$, and $\Sigma \mathrm{C}=10^{-3}$, with $\mathrm{S}$ and $\mathrm{C}$ speciation varied as a function of $\mathrm{pH}$ and redox. Eh and aqueous speciation computed using PHREEQC with wateq4f data base, ${ }^{48,49}$ and Eh-pH diagram created using Geochemist's Workbench $12 .{ }^{57}$ The dashed polygon delineates zone of likely Eh-pH conditions for the groundwater samples from the Atlantic and Gulf Coastal Plain PAs; point symbols within the polygon are measured $\mathrm{pH}$ and computed $\mathrm{Eh}$ for each sample. The computed Eh for the groundwater samples were determined using water/oxygen $\left(\mathrm{H}_{2} \mathrm{O}\right) /\left(\mathrm{O}_{2}\right)$ redox pair using Sato relation (orange dots); ${ }^{56}$ on the basis of methane/carbonate $\left(\mathrm{CH}_{4}\right) /\left(\mathrm{CO}_{3}{ }^{-2}\right)$ redox pair for methane values greater than or equal to the $0.001 \mathrm{mg} / \mathrm{L}$ reporting limit (green crosses); and on the basis of sulfide/sulfate $\left(\mathrm{H}_{2} \mathrm{~S}\right) /\left(\mathrm{SO}_{4}{ }^{-2}\right)$ redox pair assuming sulfide at equilibrium with pyrite (blue crosses). $\mathrm{Pb}$-carbonate complexes predominate except when $\mathrm{pH}$ is $<6.5$ or when conditions are strongly reducing (lowest Eh). 


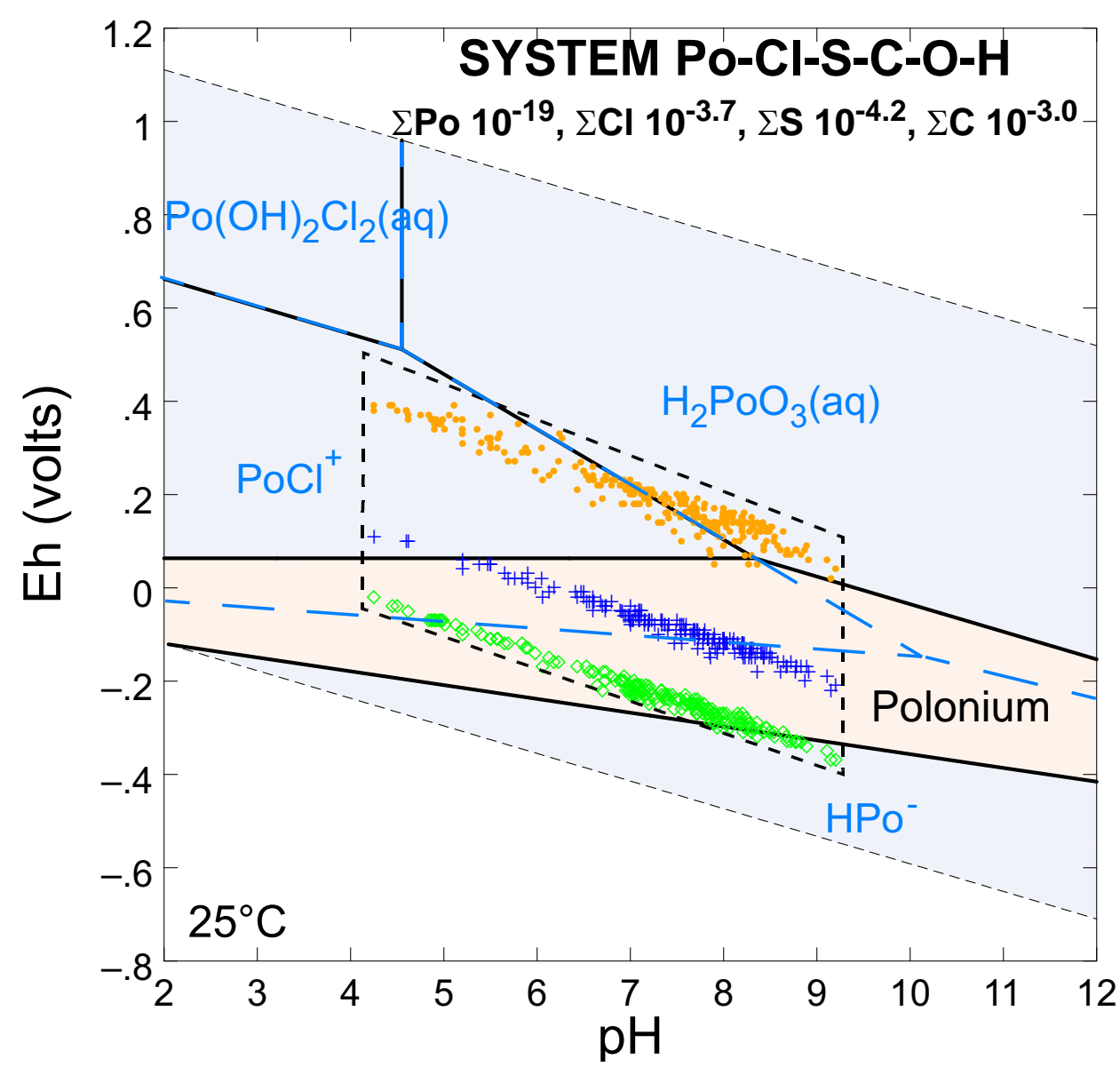

Figure SI.7A. Eh-pH diagram showing theoretical predominance fields for aqueous polonium (Po) (dashed blue-and-black lines, or dashed blue lines when overlapping with solid phase), with solid Po phase shown as solid lines. Diagram created using Geochemist's Workbench 12, ${ }^{57}$ with thermodynamic data base from Ram et al. (2019) ${ }^{50}$ including equilibrium constants for $\mathrm{Po}^{-2}$ species from Brown and Brown (2019). ${ }^{51}$ Assumed chemical activities are $\Sigma \mathrm{Po}=10^{-19}(\mathrm{Po}$ about $0.7 \mathrm{pCi} / \mathrm{L}), \Sigma \mathrm{S}=10^{-4.2}, \Sigma \mathrm{Cl}=10^{-3.7}$, and $\Sigma \mathrm{C}=10^{-3}$, with $\mathrm{S}$ and $\mathrm{C}$ speciation varied as functions of $\mathrm{pH}$ and redox. The dashed black polygon delineates zone of likely Eh-pH conditions for the groundwater samples from the Atlantic and Gulf Coastal Plain principal aquifers; point symbols within the polygon are measured $\mathrm{pH}$ and computed $\mathrm{Eh}$ for each sample. Eh computed using PHREEQC with wateq $4 \mathrm{f}$ data base ${ }^{48,49}$ on the basis of the water/oxygen $\left(\mathrm{H}_{2} \mathrm{O}\right) /\left(\mathrm{O}_{2}\right)$ redox pair using Sato relation (orange dots); ${ }^{56}$ methane/ carbonate $\left(\mathrm{CH}_{4}\right) /\left(\mathrm{CO}_{3}^{-2}\right)$ redox pair for methane values greater than or equal to the $0.001 \mathrm{mg} / \mathrm{L}$ reporting limit (green dots); and sulfide/sulfate $\left(\mathrm{H}_{2} \mathrm{~S}\right) /\left(\mathrm{SO}_{4}{ }^{-2}\right)$ redox pair assuming sulfide at equilibrium with pyrite (blue crosses). In reducing environments with $\mathrm{pH}>7.5$, aqueous $\mathrm{Po}$ species most likely are $\mathrm{H}_{2} \mathrm{PoO}_{3}$ or $\mathrm{HPo}^{-}$, which are inefficiently adsorbed. The Po speciation indicated is consistent with analogous Tellurium (Te) species $\left(\mathrm{H}_{2} \mathrm{TeO}_{3}, \mathrm{HTeO}_{3}^{-}, \mathrm{TeO}_{3}{ }^{-2}\right.$, and $\mathrm{HTe}^{-}$) shown in Figure SI-7B. 


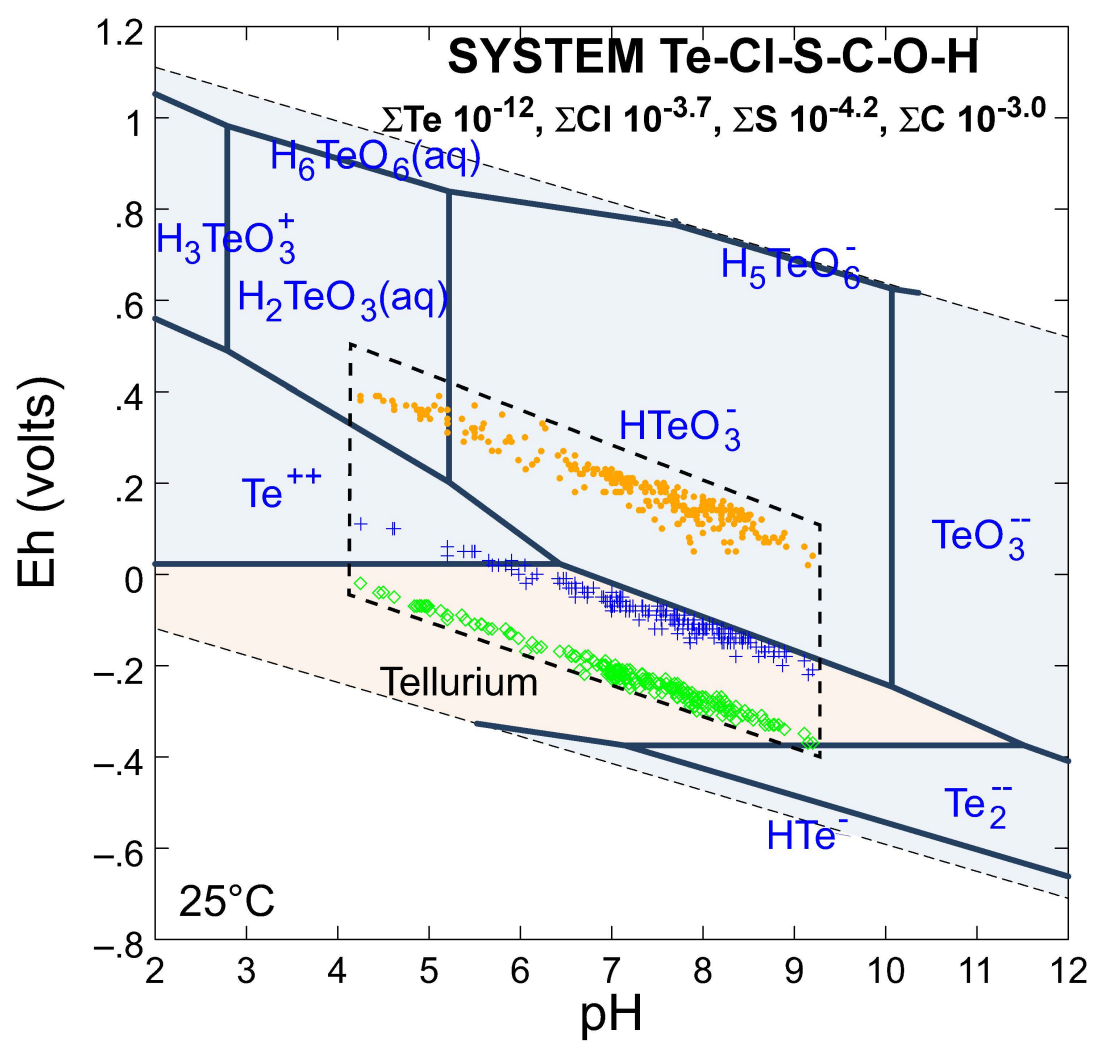

Figure SI.7B. Eh-pH diagrams showing predominance fields for aqueous Tellurium (Te). Diagrams created using Geochemist's Workbench 12,57 with data base of McPhail (1995) ${ }^{58}$ for Te augmented with thermodynamic data for $\mathrm{Te}^{+2}$. Assumed chemical activities are $\Sigma \mathrm{Te}=10^{-12}, \Sigma \mathrm{S}=10^{-4.2}, \Sigma \mathrm{Cl}=10^{-3.7}$, and $\Sigma \mathrm{C}=10^{-3}$, respectively. The Te diagram indicates aqueous Te with core valence of +4 predominates as neutral $\mathrm{H}_{2} \mathrm{TeO}_{3(\mathrm{aq})}$ at acidic $\mathrm{pH}$ and as anionic $\mathrm{HTeO}_{3}{ }^{-}$at near-neutral to alkaline $\mathrm{pH}$; core valence +2 as $\mathrm{Te}^{+2}$ at acidic $\mathrm{pH}$ and moderately reducing to oxidizing conditions; or core valence -2 as $\mathrm{HTe}^{-}$and $\mathrm{Te}^{-2}$ at extremely reducing conditions. ${ }^{50,58,59,94}$ Dashed black polygon delineates zone of likely Eh-pH conditions for groundwater samples from the Atlantic and Gulf Coastal Plain principal aquifers; point symbols within the polygon are the measured $\mathrm{pH}$ and computed Eh for each sample. Eh computed using PHREEQC with wateq4f data base. ${ }^{48,49} \mathrm{~S}$ and $\mathrm{C}$ speciation varied as functions of $\mathrm{pH}$ and redox. The computed Eh for the groundwater samples were determined using water/oxygen $\left(\mathrm{H}_{2} \mathrm{O}\right) /\left(\mathrm{O}_{2}\right)$ redox pair using Sato relation (orange dots); ${ }^{56}$ on the basis of methane/carbonate $\left(\mathrm{CH}_{4}\right) /\left(\mathrm{CO}_{3}{ }^{-2)}\right.$ redox pair for methane values greater than or equal to the $0.001 \mathrm{mg} / \mathrm{L}$ reporting limit (green crosses); and on the basis of sulfide/sulfate $\left(\mathrm{H}_{2} \mathrm{~S}\right) /\left(\mathrm{SO}_{4}^{-2}\right)$ redox pair assuming sulfide at equilibrium with pyrite (blue crosses). 


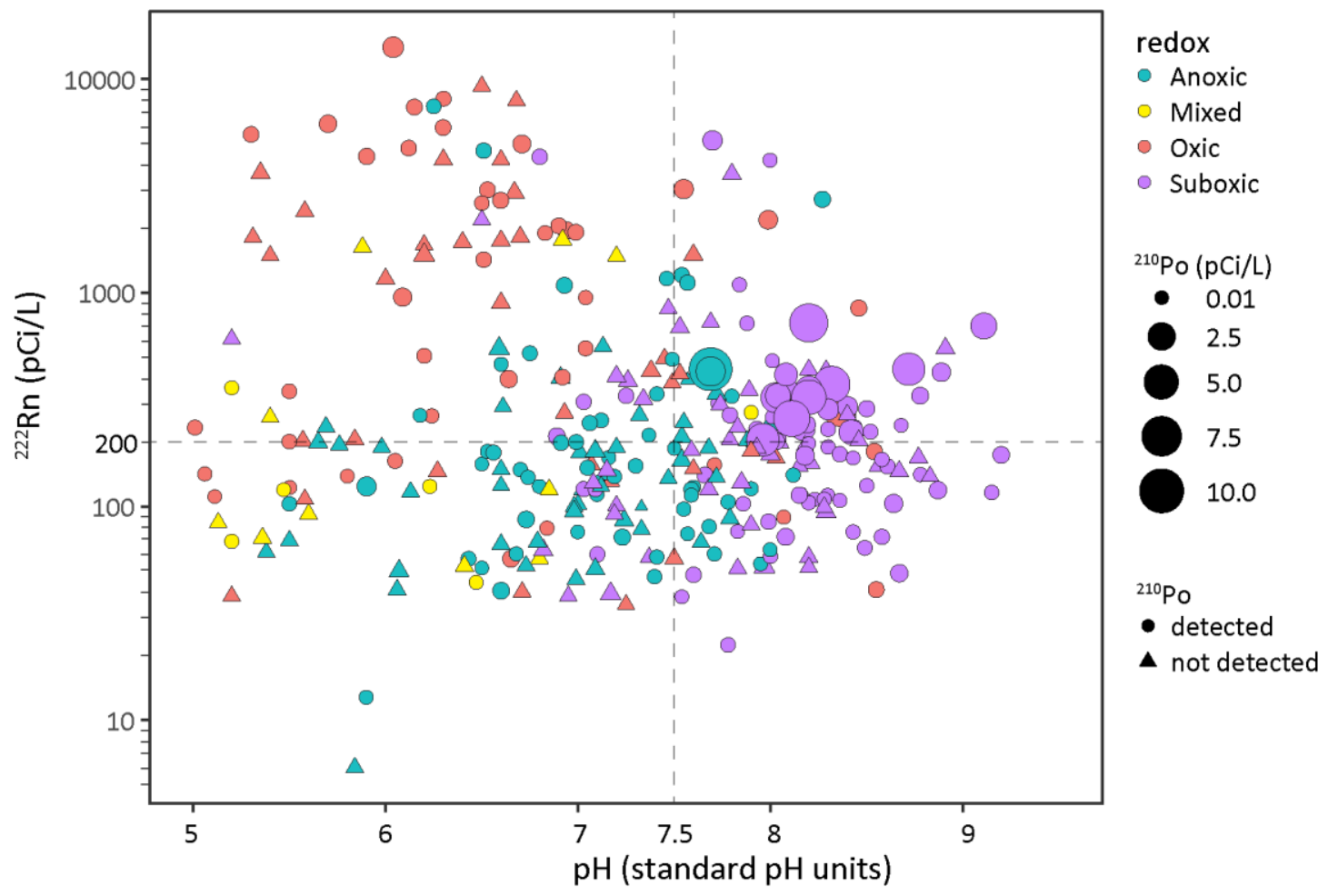

Figure SI-8. Scatter plot of concentration of ${ }^{222} \mathrm{Rn}$ as a function of $\mathrm{pH}$ for Atlantic and Gulf Coastal Plain principal aquifer samples grouped by redox category and ${ }^{210}$ Po concentration. 


\section{SUPPLEMENTAL MATERIALS REFERENCES}

(enumeration matches associated manuscript)

(7) Focazio, M.J.; Szabo, Z.; Kraemer, T.F.; Mullin, A.H.; Barringer, T.H.; DePaul, V.T. Occurrence of Selected Radionuclides in Ground Water used for Drinking Water in the United States: A Reconnaissance Survey, 1998; Water-Resources Investigation Report; USGS Numbered Series 00-4273; U.S. Geological Survey, Reston, VA, 2001; p. 39.

(25) U.S. Geological Survey. Ground Water Atlas of the United States; National Atlas HA-730 U.S. Geological Survey, Reston, VA, 2000. https://pubs.usgs.gov/ha/ha730/.

(30) Arnold, T.L.; DeSimone, L.A.; Bexfield, L.M.; Lindsey, B.D.; Barlow, J.R.; Kulongoski, J.T.; Musgrove, M.L.; Kingsbury, J.A.; Belitz, K. Groundwater Quality Data from the National Water-Quality Assessment Project, May 2012 through December 2013; USGS Data Series 997; U.S. Geological Survey, Reston, VA, 2016; p. 56. http://dx.doi.org/10.3133/ds997

(33) Arnold, T.L.; Bexfield, L.M.; Musgrove, M.L.; Lindsey, B.D.; Stackelberg, P.E.; Barlow, J.R.; DeSimone, L.A.; Kulongoski, J.T; Kingsbury, J.A.; Ayotte, J.D.; Fleming, B.J.; Belitz, K. Groundwater-Quality Data from the National Water-Quality Assessment Project, January through December 2014 and Select Quality-Control Data from May 2012 through December 2014; USGS Data Series 1063; U.S. Geological Survey, Reston, VA, 2017; p. 83. https://doi.org/10.3133/ds1063

(34) Arnold, T.L.; Bexfield, L.M.; Musgrove, M.L.; Stackelberg, P.E.; Lindsey, B.D.; Kingsbury, J.A.; Kulongoski, J.T.; Belitz, K. Groundwater-Quality and Select Quality-Control Data from the National Water-Quality Assessment Project, January through December 2015, and Previously Unpublished Data from 2013 to 2014; USGS Data Series 1087, U.S. Geological Survey, Reston, VA, 2018; p. 68. https://doi.org/10.3133/ds1087

(46) McMahon, P.B.; Chapelle, F.H. Redox processes and water quality of selected principal aquifer systems. Ground Water 2008, 46, 259-271.

(48) Parkhurst, D.L.; Appelo, C.A.J. Description of Input and Examples for PHREEQC Version 3: a Computer Program for Speciation, Batch-Reaction, One-Dimensional Transport, and Inverse Geochemical Calculations; USGS Techniques and Methods; U.S. Geological Survey, Reston, VA, 2013; p. 519.

(49) Ball, J.W.; Nordstrom, D.K. User's Manual for WATEQ4F with Revised Data Base; U.S. Geological Survey. OpenFile Report; USGS Numbered Series 91-183; U.S. Geological Survey, Reston, VA, 1991; p.

189. http://wwwbrr.cr.usgs.gov/projects/GWC_chemtherm/pubs/wq4fdoc.pdf.

(50) Ram, R.; Vaughan, J.; Etschmann, B.; Brugger, J. The aqueous chemistry of polonium (Po) in environmental and anthropogenic processes. J. Hazard. Mater. 2019, 380, 120725. https://doi.org/10.1016/j.jhazmat.2019.06.002

(51) Brown, S.A.; Brown, P.L. The Aqueous Chemistry of Polonium and the Practical Application of its Thermochemistry; Elsevier, Amsterdam, 2019; p. 220. ISBN 29780128193082.

(56) Sato, M. Oxidation of sulfide ore bodies 1. Geochemical environments in terms of Eh and pH. Econ. Geol. Bull. Soc. Econ. Geol. 1960, 55, 928-961.

(57) Bethke, C.M.; Farrell, B.; Yeakel S. The Geochemist's Workbench release 12, GWB Essentials Guide; Aqueous Solutions, LLC; Champaign, IL, 2018; p. 186.

(58) McPhail, D.C. Thermodynamic properties of aqueous tellurium species between 25 and $350^{\circ}$ C. Geochim. Cosmochim. Acta 1995, 59, 851-866.

(59) Ansoborlo, E.; Berard, P.; Den Auwer, C.; Leggett, R.; Menetrier, F.; Younes, A.; Montavon, G.; Moisy, P. Review of chemical and radiotoxicological properties of polonium for internal contamination purposes. Chem. Res. Toxicol. 2012, 25(8), 1551-1564. https://doi.org/10.1021/tx300072w

(94) Hayes, S.M.; Ramos, N.A. Surficial geochemistry and bioacessibility of tellurium in semiarid mine tailings. Environ. Chem. 2019, 16(4), 251-265.

(111) Arnold, T.L., DeSimone, L.A., Bexfield, L.M., Lindsey, B.D., Barlow, J.R., Kulongoski, J.T., Musgrove, M.L., Kingsbury, Belitz, K. 2016, Groundwater Quality Data from the National Water Quality Assessment Project, May 2012 through December 2013; USGS data release, U.S. Geological Survey, Reston, VA, 2016. https://dx.doi.org/10.5066/F7HQ3X18.

(112) Arnold, T.L., Bexfield, L.M., Musgrove, M.L., Lindsey, B.D., Stackelberg, P.E., Barlow, J.R., DeSimone, L.A., Kulongoski, J.T., Kingsbury, J.A., Ayotte, J.D., Fleming, B.J., Belitz, K. Datasets from groundwater-quality data 
from the National Water-Quality Assessment Project, January through December 2014 and select quality-control data from May 2012 through December 2014; USGS data release; U.S. Geological Survey, Reston, VA, 2017. https://doi.org/10.5066/F7W0942N.

(113) Arnold, T.L., Bexfield, L.M., Musgrove, M.L., Lindsey, B.D., Stackelberg, P.E., Lindsey, B.D., Barlow, J.R., Kulongoski, J.T., Belitz, K, Datasets from Groundwater-Quality and Select Quality-Control Data from the National Water-Quality Assessment Project, January through December 2015 and Previously Unpublished Data from 2013-2014; USGS data release; U.S. Geological Survey, Reston, VA, 2018. https://doi.org/10.5066/F7XK8DHK.

(114) Arnold, T.L., Sharpe, J.B., Bexfield, L.M., Musgrove, M.L., Erickson, M.L., Kingsbury, J.A., Degnan, J.R., Tesoriero, A.J., Kulongoski, J.T., Belitz, K. Datasets from groundwater-quality and select quality-control data from the National Water-Quality Assessment Project, January through December 2016, and previously unpublished data from 2013 to 2015; USGS data release; U.S. Geological Survey, Reston, VA, 2020. https://doi.org/10.5066/P9W4RR74. 